\title{
The relationship of different levels of high iodine and goiter in school children: a meta-analysis
}

\author{
Tingting Xu, Zhiyuan Ren, Shaohan Li, Long Tan* and Wanqi Zhang
}

\begin{abstract}
Background: Over the past decade, the phenomenon of high urine iodine (HUI) and high water iodine (HWI) has become more common. But the risk of goiter caused by different levels of HUI and HWI remains unclear.

Objectives: To explore the risk of goiter development caused by HUI and HWI, and compare the risk of goiter development from different levels of high iodine.

Methods: The Medline, Cochrane library, Embase, China National Knowledge Infrastructure and Wan fang databases were searched for relevant population-based studies investigating the link between high iodine levels and goiter development in mainland China. Three reviewers extracted data from the included studies independently, assessing the prevalence of goiter development due to high iodine.

Results: Taking $100 \mu \mathrm{g} / \mathrm{L} \leq \mathrm{UIC}<300 \mu \mathrm{g} / \mathrm{L}$ (UIC= urinary iodine concentration) as the reference group, the odds ratio $(\mathrm{OR})$ regarding high iodine levels and goiter formation was $1.74(95 \% \mathrm{Cl} 1.50,2.01, P<0.001)$, if the water iodine concentration (WIC) was greater than $100 \mu \mathrm{g} / \mathrm{L}$, the OR between goiter development and WIC was $4.74(95 \% \mathrm{Cl} 1.15$, $19.46, P=0.001)$. The Linear trend analysis of HUI and goiter showed that the prevalence of goiter increased with the increase of UIC $\left(X^{2}=734.605, P<0.001\right)$.

Conclusions: When the UIC $\geq 300 \mu \mathrm{g} / \mathrm{L}$ or the WIC $\geq 100 \mu \mathrm{g} / \mathrm{L}$, the risk of goiter will increase. The higher the UIC, the greater the risk of goiter development. In order to improve the public thyroid health, we should adhere to the monitoring of urinary iodine and water iodine, and keep them at an appropriate level.
\end{abstract}

Trial registration: PROSPEROCR, CRD42020197620. Registered 8 August 2020, https://www.crd.york.ac.uk/PROSP $\mathrm{ERO} /$.

Keywords: High urinary iodine, High water iodine, Goiter, School children, Meta-analysis

\section{Introduction}

Iodine is an essential trace element in the human body and is a crucial component of both thyroxin and triiodothyronine, key hormones produced by the thyroid. Iodine exerts its physiological function through these hormones,

*Correspondence: tanlong@tmu.edu.cn

Department of Nutrition and Food Hygiene, School of Public Health, Tianjin Medical University, Heping District, No. 22, Qixiangtai Road, Tianjin, China promoting material and energy metabolism and allowing growth and development. Insufficient iodine intake can lead to an iodine deficiency, which in turn will manifest itself as specific health problems such as goiter development or endemic cretinism [1, 2]. The adopted global strategy of universal salt iodization has begun to combat iodine deficiencies and has significantly improved the health of the global population [3]. However, iodine intake must be kept in balance; excessive iodine levels will lead to adverse effects just as insufficient iodine original author(s) and the source, provide a link to the Creative Commons licence, and indicate if changes were made. The images or other third party material in this article are included in the article's Creative Commons licence, unless indicated otherwise in a credit line to the material. If material is not included in the article's Creative Commons licence and your intended use is not permitted by statutory regulation or exceeds the permitted use, you will need to obtain permission directly from the copyright holder. To view a copy of this licence, visit http://creativecommons.org/licenses/by/4.0/. The Creative Commons Public Domain Dedication waiver (http://creativeco mmons.org/publicdomain/zero/1.0/) applies to the data made available in this article, unless otherwise stated in a credit line to the data. 
levels will. An excessive iodine intake can lead to thyroid dysfunction; this can cause multiple health conditions including: hypothyroidism, hyperthyroidism, autoimmune thyroiditis and goiter formation $[4,5]$.

High iodine levels can be caused by dietary intake, with food high in iodine and iodized salt proving problematic; high background levels of iodine in drinking water may also cause this and exacerbate the problem of a high dietary intake. Both the WHO and the Chinese government recommended monitoring goiter rates in children as an indicator for long-term iodine nutrition in the population [6]. When iodine exposure is high, it is thought that the prevalence of children with goiters will exceed 5\%. A cross-sectional survey of areas with high levels of iodine in the water was conducted in northern China; it was found that in area where water iodine levels exceeded than $300 \mu \mathrm{g} / \mathrm{L}$, the population's urinary iodine concentration (UIC) was on average $476.3 \mu \mathrm{g} / \mathrm{L}$, with a goiter prevalence of $10 \%$ [7]. It was also shown that when iodized table salt was consumed in areas with high iodine level water (iodine salt concentration of $10.4-34.1 \mathrm{mg} / \mathrm{kg}$ ), the average UIC increased to $518 \mu \mathrm{g} / \mathrm{L}$ and the prevalence of goiters was $32.96 \%$ [8].

However, the risk of goiter development caused by different levels of high iodine intake was still unclear. Therefore, the aim of this study was to clarify the risk of high iodine intake on goiter development. It also aimed to evaluate the relationship between different high urinary iodine levels (HUI) and high water iodine (HWI) and the prevalence of goiters in these populations, using a metaanalysis approach.

\section{Materials and methods}

The review was registered in the PROSPERO International Prospective Register of Systematic Reviews (https://www.crd.york.ac.uk/prospero; CRD number: 42020197620).

\section{Literature search}

Medline, Embase, Cochrane library, China National Knowledge Infrastructure (CNKI) and Wan Fang databases were searched by computer from database inception to March 2020. The reference list generated was then manually searched. The Medline, Embase and Cochrane library database searches used the following search terms: (('Iodine' OR 'iodide') AND 'excess' OR 'high' OR 'excessive') AND 'goiter'. The search terms ("high or excess" and "iodine" and "goiter" (in Chinese)) were used to search the CNKI and Wan Fang databases.

\section{Inclusion and exclusion criteria}

HUI level was defined in accordance with the standards of the WHO/UNICEF/ICCIDD [9] and HWI level was defined in accordance with the standards of GB193802016 [10]. The defined standard of HUI used $300 \mu \mathrm{g} / \mathrm{L}$ UIC as cut-off value for school-age children and adults; the standard for HWI level was defined as $100 \mu \mathrm{g} / \mathrm{L}$ water iodine concentration (WIC). Therefore, the following studies were included in this meta-analysis (Fig. 1): (1) cross-sectional studies that defined a high iodine intake group using a UIC cut-off of $300 \mu \mathrm{g} / \mathrm{L}$ for schoolage children, with controls selected from populations with average or slightly elevated intakes (cut-off values for average and slightly elevated iodine intakes were 100$200 \mu \mathrm{g} / \mathrm{L}$ and $200-300 \mu \mathrm{g} / \mathrm{L}$ UIC in school-age children, respectively); (2) cross-sectional studies that defined the group of areas with high water iodine levels using a WIC cut-off of $100 \mu \mathrm{g} / \mathrm{L}$, whereas the controls were selected from populations with normal water iodine levels ( Normal water iodine levels were $\leq 100 \mu \mathrm{g} / \mathrm{L}$ in WIC). In cases of repeated publication, only the first published article was included. Only articles published in English or Chinese were considered. Animal studies, case reports, reviews, studies not reporting sample size and studies with incomplete data, were all excluded.

\section{Data extraction and quality evaluation}

Data was independently extracted by three authors from the included studies ( $\mathrm{Li} \mathrm{SH}$, Ren ZY and Xu TT). When the results from the literature were uncertain, it was discussed between the authors before reaching a final agreement. The following data were extracted from included literatures: surname of first author, publish time, study time, UIC, WIC, the number of patients with goiters,

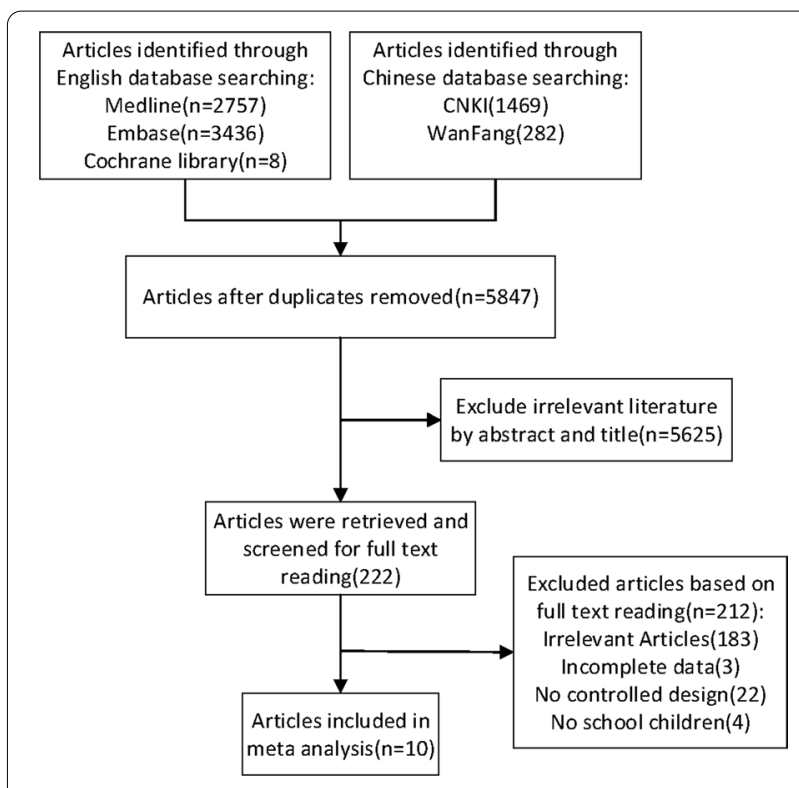

Fig. 1 A flow chart of the literature search used for this meta-analysis 
total number of researchers and the prevalence of goiters. The methodological quality of the included studies was assessed using the cross-sectional study evaluation scale recommended by the Agency for Healthcare Research and Quality (AHRQ) [11]. There were 11 criteria to this scale. Each criterion included three options: "yes", "no" and "unclear". A "yes" scored 1 point whereas "unclear" or "no" scored 0 points. Article quality was assessed as follows: low quality $=0-3$; moderate quality $=4-7$; high quality $=8-11$. The evaluation results of the 11 studies included in the meta-analysis are shown in Table 1 . This assessment was performed by 2 authors (Li SH and Ren $\mathrm{ZY}$ ) independently, with a third author (Xu TT) being consulted to settle disagreements.

\section{Statistical analysis}

Stata software 16.0 and RevMan 5.3 were used to perform the meta-analysis. The odds ratio (OR) and $95 \%$ confidence interval $(\mathrm{CI})$ were the statistical effect size used to estimate the effect of iodine exposure. A $P<0.05$ was considered statistically significant. The $\mathrm{I}^{2}$ test was used to quantify heterogeneity [12]. According to the Cochrane Handbook for Systematic Reviews [13], if the $\mathrm{I}^{2}$ value was less than $50 \%$, the heterogeneity could be accepted, and the fixed-effects model was used. If high levels of heterogeneity $\left(\mathrm{I}^{2}>50 \%\right)$ were detected between the studies, the random-effects model was selected. If different subgroups of the same group required different models, the random-effects model was used. The presence of publication bias was examined using the Begg's test [14], $P>0.1$ was considered statistically significant. The subgroup analyses of the prevalence of goiter with different HUI and the prevalence of goiter with different HWI would be done. Mantel Haenszel $\chi^{2}$ test was used for linear trend analysis of $\mathrm{HI}$ and goiter.

\section{Results}

\section{Literature search and the characteristics of the included studies}

During the initial database search, 5847 articles were retrieved. Following an initial screening based on the paper title and abstract, 222 articles were retrieved and screened for full text reading. Of the 222 papers, 183 were found irrelevant, 3 had incomplete data, 22 did not have a controlled design and 4 did not examine school age children. Consequently, 10 studies were included in the meta-analysis [15-24] (Fig. 1). The characteristics of these studies are listed in Table 1.

\section{High urinary iodine and goiter}

The association between HUI and the prevalence of goiters is shown in Fig. 2. A UIC of $100-300 \mu \mathrm{g} / \mathrm{L}$ was selected as the reference group. 7 articles reported the prevalence of goiters, which included 16 studies. These 16 studies included 104,645 subjects. There were 49,244 subjects from the UIC $\geq 300 \mu \mathrm{g} / \mathrm{L}$ group and 55,401 subjects from the $100-300 \mu \mathrm{g} / \mathrm{L}$ group. The OR value was 1.74 (95\% CI 1.50, 2.01, $P<0.001)$. It indicated that a UIC $\geq 300 \mu \mathrm{g} / \mathrm{L}$ was associated with an increased risk of developing a goiter compared to a UIC from 100$300 \mu \mathrm{g} / \mathrm{L}$. The result of the Begg's test and Egger's test were $P=0.163>0.1$, indicating that there was no significant publication bias.

\section{High water iodine and goiter}

The association between HWI $(>100 \mu \mathrm{g} / \mathrm{L})$ and the development of goiters was shown in Fig. 3. Three articles reported the development of goiters. These studies included 879 subjects (632 subjects from the high iodine group and 247 subjects from the control group). None of the studies crossed the invalid line. The OR value was $4.74(95 \%$ CI $1.15,19.46, P=0.008)$. This indicated that a WIC $>100 \mu \mathrm{g} / \mathrm{L}$ was associated with an increased risk of goiter development compared with $\mathrm{WI} \leq 100 \mu \mathrm{g} / \mathrm{L}$. Owing to the limited number of studies included in this aspect of the analysis, publication bias was not assessed.

\section{Subgroup analysis Prevalence of goiter with different high urinary iodine levels} The associations between different levels of HUI and the prevalence of goiters were shown in Fig. 4. Taking a UIC of $100-300 \mu \mathrm{g} / \mathrm{L}$ as the reference group, the risk of goiter development was assessed in groups with a UIC of $300-500 \mu \mathrm{g} / \mathrm{L}, 500-800 \mu \mathrm{g} / \mathrm{L}, 800-1000 \mu \mathrm{g} / \mathrm{L}$ and $\geq 1000 \mu \mathrm{g} / \mathrm{L}$. The OR values were 1.67 (95\% CI 1.42, 1.97, $P<0.001$ ), 1.78 (95\% CI 1.57, 2.00, $P<0.001$ ), 2.13 (95\% CI 1.56, 2.91, $P<0.001$ ) and 2.11 (95\% CI 1.40, 3.18, $P<0.001)$, respectively. The overall risk of high iodine causing goiter development was $\mathrm{OR}=1.84$ (95\% CI 1.63, $2.07, P<0.001)$.

\section{Linear trend analysis of high iodine and goiter Linear trend analysis of HUI and goiter}

The linear-by-linear association between different levels of HUI and the prevalence of goiter are shown in Table 2. The urine iodine concentration was divided into five groups from low to high as follows: 100-300, 300-500, 500-800, 800-1000, $\geq 1000 \mu \mathrm{g} / \mathrm{L}$ for Mantel Haenszel $\chi^{2}$ test. The result showed that there was a linear correlation between the UIC and the prevalence of goiter $\left(X^{2}=734.605, P<0.001\right)$. And with the increase of UIC, the prevalence of goiter also increased. 
Table 1 The characteristics of 14 cross-sectional studies

\begin{tabular}{|c|c|c|c|c|c|c|c|c|}
\hline Author & Publish time & Study time & UIC ( $\mu \mathrm{g} / \mathrm{L})$ & WIC (mg/L) & $\mathrm{n}$ & $\mathbf{N}$ & $\begin{array}{l}\text { Prevalence of } \\
\text { goiter }\end{array}$ & $\begin{array}{l}\text { Quality } \\
\text { evaluation }\end{array}$ \\
\hline \multirow[t]{50}{*}{ Liu [15] } & 2010 & 1999 & 13.2 & - & 12 & 82 & 14.6 & 7 \\
\hline & & & 37.3 & - & 20 & 379 & 5.2 & \\
\hline & & & 77.7 & - & 89 & 1015 & 8.8 & \\
\hline & & & 125.5 & - & 84 & 1193 & 7.0 & \\
\hline & & & 174.3 & - & 78 & 1329 & 5.9 & \\
\hline & & & 248.1 & - & 199 & 2731 & 7.3 & \\
\hline & & & 378.0 & - & 350 & 3682 & 9.5 & \\
\hline & & & 599.1 & - & 237 & 2026 & 11.7 & \\
\hline & & & 865.3 & - & 44 & 364 & 12.2 & \\
\hline & & & 1157.5 & - & 14 & 183 & 7.5 & \\
\hline & & 2002 & 13.6 & - & 14 & 108 & 13.0 & \\
\hline & & & 36.2 & - & 14 & 297 & 4.7 & \\
\hline & & & 77.3 & - & 47 & 876 & 5.4 & \\
\hline & & & 125.7 & - & 48 & 1225 & 3.9 & \\
\hline & & & 174.7 & - & 57 & 1321 & 4.3 & \\
\hline & & & 245.2 & - & 135 & 2322 & 5.8 & \\
\hline & & & 371.0 & - & 140 & 2160 & 6.5 & \\
\hline & & & 547.7 & - & 48 & 650 & 7.4 & \\
\hline & & & 862.2 & - & 11 & 86 & 12.9 & \\
\hline & & & 1274.4 & - & 3 & 56 & 6.0 & \\
\hline & & 2005 & 10.6 & - & 19 & 172 & 11.0 & \\
\hline & & & 36.0 & - & 33 & 426 & 7.7 & \\
\hline & & & 77.7 & - & 62 & 1109 & 5.6 & \\
\hline & & & 125.9 & - & 64 & 1392 & 4.6 & \\
\hline & & & 175.8 & - & 72 & 1503 & 4.8 & \\
\hline & & & 251.8 & - & 130 & 3012 & 4.3 & \\
\hline & & & 368.1 & - & 141 & 2476 & 5.7 & \\
\hline & & & 574.8 & - & 39 & 703 & 5.5 & \\
\hline & & & 868.0 & - & 2 & 77 & 2.6 & \\
\hline & & & 1200.0 & - & 7 & 69 & 10.1 & \\
\hline & & 2005 & 11.3 & - & 1 & 53 & 1.9 & \\
\hline & & & 37.2 & - & 5 & 126 & 4.0 & \\
\hline & & & 76.5 & - & 22 & 386 & 5.7 & \\
\hline & & & 127.5 & - & 39 & 662 & 5.9 & \\
\hline & & & 175.2 & - & 47 & 783 & 6.0 & \\
\hline & & & 252.2 & - & 142 & 1824 & 7.8 & \\
\hline & & & 393.8 & - & 452 & 3895 & 11.6 & \\
\hline & & & 762.0 & - & 359 & 2621 & 13.7 & \\
\hline & & & 868.0 & - & 114 & 675 & 16.9 & \\
\hline & & & 1200.0 & - & 273 & 1531 & 17.8 & \\
\hline & & 2007 & 13.2 & - & 237 & 2419 & 9.8 & \\
\hline & & & 46.2 & - & 807 & 6612 & 12.2 & \\
\hline & & & 81.0 & - & 786 & 9251 & 8.5 & \\
\hline & & & 124.4 & - & 548 & 7205 & 7.6 & \\
\hline & & & 154.6 & - & 454 & 6401 & 7.1 & \\
\hline & & & 244.5 & - & 832 & 10,274 & 8.1 & \\
\hline & & & 357.2 & - & 764 & 8129 & 9.4 & \\
\hline & & & 575.4 & - & 195 & 1623 & 12.0 & \\
\hline & & & 875.6 & - & 11 & 96 & 11.5 & \\
\hline & & & 1273.4 & - & 13 & 77 & 16.9 & \\
\hline
\end{tabular}


Table 1 (continued)

\begin{tabular}{|c|c|c|c|c|c|c|c|c|}
\hline Author & Publish time & Study time & UIC $(\mu \mathrm{g} / \mathrm{L})$ & WIC (mg/L) & $n$ & $\mathrm{~N}$ & $\begin{array}{l}\text { Prevalence of } \\
\text { goiter }\end{array}$ & $\begin{array}{l}\text { Quality } \\
\text { evaluation }\end{array}$ \\
\hline \multirow[t]{2}{*}{ Wang [16] } & 2015 & 2012 & 271.0 & - & 11 & 291 & 3.8 & 7 \\
\hline & & & 692.6 & - & 28 & 300 & 9.3 & \\
\hline \multirow[t]{2}{*}{ Xiao [17] } & 2011 & 2007 & 319.2 & - & 61 & 731 & 8.3 & 7 \\
\hline & & & 189.8 & - & 69 & 1248 & 5.5 & \\
\hline \multirow[t]{4}{*}{ Jia [18] } & 2014 & 2014 & 74.3 & 73.8 & 11 & 196 & 5.6 & 7 \\
\hline & & & 312.8 & 144.7 & 25 & 189 & 13.2 & \\
\hline & & & 455.6 & 258.5 & 20 & 158 & 12.6 & \\
\hline & & & 793.5 & 501.0 & 18 & 165 & 10.9 & \\
\hline \multirow[t]{2}{*}{ Wang [19] } & 2015 & 2014 & 514.0 & 304.4 & 9 & 100 & 9.0 & 7 \\
\hline & & & 196.17 & 141.6 & 1 & 100 & 1.0 & \\
\hline \multirow[t]{3}{*}{ Yu [20] } & 2008 & 1999 & 83.5 & - & 192 & 2708 & 7.1 & 10 \\
\hline & & & 242.9 & - & 119 & 2708 & 4.4 & \\
\hline & & & 650.9 & - & 187 & 2708 & 6.9 & \\
\hline \multirow[t]{2}{*}{ Liu [21] } & 2007 & - & 480.4 & $>150.0$ & 108 & 1458 & 7.4 & 6 \\
\hline & & & 228.0 & $\leq 150.0$ & 22 & 1229 & 1.8 & \\
\hline \multirow[t]{5}{*}{ Tang [22] } & 2006 & - & 612.5 & $124.2 \pm 88.2$ & 141 & 1184 & 11.9 & 6 \\
\hline & & & 269.4 & $136.6 \pm 89.2$ & 95 & 889 & 10.7 & \\
\hline & & & 642.9 & $183.0 \pm 190.2$ & 148 & 1133 & 13.1 & 6 \\
\hline & & & 244.5 & $124.1 \pm 105.1$ & 129 & 862 & 9.7 & \\
\hline & & & 499.7 & $112.3 \pm 85.3$ & 114 & 1032 & 11.1 & \\
\hline \multirow[t]{4}{*}{ Jia [23] } & 2006 & - & 460.5 & $>150.0$ & 84 & 570 & 14.7 & \\
\hline & & & & & 35 & 269 & 13.1 & \\
\hline & & & 310.3 & $\leq 150.0$ & 60 & 656 & 9.1 & 6 \\
\hline & & & & & 23 & 316 & 7.3 & \\
\hline \multirow[t]{10}{*}{ Dai [24] } & 2013 & 2004-2010 & 433.3 & - & 55 & 211 & 26.1 & \\
\hline & & & 296.1 & - & 16 & 235 & 6.8 & \\
\hline & & & 313.9 & - & 20 & 216 & 9.3 & 7 \\
\hline & & & 345.9 & - & 19 & 208 & 9.1 & \\
\hline & & & 199.8 & - & 14 & 237 & 5.9 & \\
\hline & & & - & $\leq 100.0$ & 91 & 247 & 36.8 & \\
\hline & & & - & $100.0-200.0$ & 573 & 2019 & 26.4 & \\
\hline & & & - & $200.0-300.0$ & 294 & 1189 & 24.7 & \\
\hline & & & - & $300.0-400.0$ & 205 & 648 & 31.6 & \\
\hline & & & - & $>400.0$ & 741 & 2230 & 33.2 & \\
\hline
\end{tabular}

\section{Discussion}

This study explored the relationship between high iodine levels and the prevalence of goiter development through a meta-analysis of the 10 cross-sectional studies, using UIC and WIC as indicators of iodine exposure. For ethical reasons, it is difficult to conduct a randomized controlled trial exploring the effects of high iodine exposure on goiter development. Therefore, it was speculated that the inclusion of cross-sectional studies in our meta-analysis might help to account for the association between high iodine levels and goiter development among school children.
UIC was the most common and practical marker used to estimate population iodine levels and their iodine intake $[25,26]$. This is because $>90 \%$ of dietary iodine is readily excreted in urine [27]. Using urinary iodine levels as a marker for iodine exposure, it was found that there was a higher prevalence of goiter development in people with a high iodine intake (UIC $\geq 300 \mu \mathrm{g} / \mathrm{L}$ ) when compared to those with a normal and slightly elevated intake $(100 \mu \mathrm{g} / \mathrm{L} \leq \mathrm{UIC}<300 \mu \mathrm{g} / \mathrm{L})$. Moreover, the linear trend analysis showed that the prevalence of goiter development generally increased as iodine intake increased. 


\begin{tabular}{|c|c|c|c|c|c|c|c|c|c|c|}
\hline Study or Subgroup & \multicolumn{2}{|c|}{$\geqslant 300 \mu g / L$} & \multicolumn{2}{|c|}{$100-300 \mu \mathrm{g} / \mathrm{L}$} & Weight & $\begin{array}{c}\text { Odds Ratlo } \\
\text { M-H, Random, } 95 \% \text { Cl }\end{array}$ & \multicolumn{4}{|c|}{$\begin{array}{c}\text { Odds Ratlo } \\
\text { M-H, Random, } 95 \% \mathrm{Cl}\end{array}$} \\
\hline Liu P 2010 & 788 & 8302 & 832 & 10274 & $9.7 \%$ & $1.19[1.07,1.32]$ & & & $=$ & \\
\hline Liu P 2010 & 182 & 3250 & 136 & 2895 & $8.2 \%$ & $1.20[0.96,1.51]$ & & & $=$ & \\
\hline Liu P 2010 & 189 & 3325 & 130 & 3012 & $8.2 \%$ & $1.34[1.06,1.68]$ & & & $=$ & \\
\hline Liu P 2010 & 202 & 2952 & 240 & 4868 & $8.7 \%$ & $1.42[1.17,1.72]$ & & & 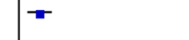 & \\
\hline Xiao B Z 2011 & 61 & 731 & 69 & 1248 & $6.3 \%$ & $1.56[1.09,2.22]$ & & & $\mp$ & \\
\hline Yu X 2008 & 187 & 2708 & 119 & 2708 & $8.1 \%$ & $1.61[1.27,2.04]$ & & & $=$ & \\
\hline Jia Q 2014 & 18 & 165 & 16 & 235 & $3.0 \%$ & $1.68[0.83,3.39]$ & & & 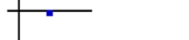 & \\
\hline Liu P 2010 & 983 & 9925 & 1002 & 16456 & $9.8 \%$ & $1.70[1.55,1.86]$ & & & - & \\
\hline Liu P 2010 & 645 & 6255 & 331 & 5253 & $9.3 \%$ & $1.71[1.49,1.96]$ & & & - & \\
\hline Liu P 2010 & 1198 & 8722 & 228 & 3269 & $9.2 \%$ & $2.12[1.83,2.46]$ & & & 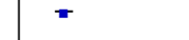 & \\
\hline Liu P 2010 & 7 & 69 & 136 & 2895 & $2.5 \%$ & $2.29[1.03,5.10]$ & & & & \\
\hline Jia Q 2014 & 45 & 347 & 11 & 196 & $3.2 \%$ & $2.51[1.26,4.97]$ & & & 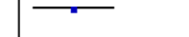 & \\
\hline Dai HX 2013 & 94 & 635 & 30 & 472 & $5.4 \%$ & $2.56[1.67,3.93]$ & & & - & \\
\hline Wang Yang 2015 & 28 & 300 & 11 & 291 & $2.9 \%$ & $2.62[1.28,5.37]$ & & & 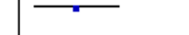 & \\
\hline Liu H 2007 & 108 & 1458 & 22 & 1229 & $5.0 \%$ & $4.39[2.76,6.99]$ & & & 7 & \\
\hline Wang Y 2015 & 9 & 100 & 1 & 100 & $0.5 \%$ & $9.79[1.22,78.81]$ & & & & \\
\hline Total $(95 \% \mathrm{Cl})$ & & 49244 & & 55401 & $100.0 \%$ & $1.74[1.50,2.01]$ & & & $\bullet$ & \\
\hline Total events & 4744 & & 3314 & & & & & & & \\
\hline $\begin{array}{l}\text { Heterogeneity: } \text { Tau }^{2}= \\
\text { Test for overall effect: }\end{array}$ & $\begin{array}{l}.05 ; \mathrm{Chi}^{2} \\
=7.42(\mathrm{P}\end{array}$ & $\begin{array}{l}=88.38 \\
0<0.00\end{array}$ & $\begin{array}{l}\mathrm{df}=15(\mathrm{C} \\
001)\end{array}$ & $P<0.00$ & $0001) ;\left.\right|^{2}=$ & $83 \%$ & 0.01 & 0.1 & 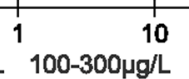 & $100^{\circ}$ \\
\hline
\end{tabular}

\begin{tabular}{|c|c|c|c|c|c|c|c|c|c|c|}
\hline Study or Subgroup & $\begin{array}{l}>100 \mathrm{mg} \\
\text { Events }\end{array}$ & $\begin{array}{l}\text { g/L } \\
\text { Total }\end{array}$ & $\begin{array}{l}\leqslant 100 \mathrm{~m} \\
\text { Events }\end{array}$ & $\begin{array}{l}g / L \\
\text { Total }\end{array}$ & Woight & $\begin{array}{c}\text { Odds Ratlo } \\
\text { M-H, Random, } 95 \% \mathrm{Cl}\end{array}$ & & $\begin{array}{r}\text { Odds } \\
M-H, \text { Rand }\end{array}$ & $\begin{array}{l}3 \text { Ratio } \\
\text { dom, } 95 \% \mathrm{Cl}\end{array}$ & \\
\hline Jia Q 2014 & 63 & 512 & 11 & 196 & $51.7 \%$ & $2.36[1.22,4.58]$ & & & $\rightarrow-$ & \\
\hline Mu L 1987 & 78 & 120 & 8 & 51 & $48.3 \%$ & $9.98[4.30,23.19]$ & & & & \\
\hline Total $(95 \% \mathrm{Cl})$ & & 632 & & 247 & $100.0 \%$ & $4.74[1.15,19.46]$ & & & & \\
\hline Total events & 141 & & 19 & & & & & & & \\
\hline \multicolumn{7}{|c|}{$\begin{array}{l}\text { Heterogeneity: } \text { Tau }^{2}=0.89 ; \mathrm{Ch}^{2}=6.95, \mathrm{df}=1(P=0.008) ; \mathrm{l}^{2}=86 \% \\
\text { Test for overall effect: } Z=2.16(P=0.03)\end{array}$} & 0.01 & $\stackrel{0.1}{>100 \mathrm{mg} / \mathrm{L}}$ & $1 \leqslant 100 \mathrm{mg} / \mathrm{L}$ & 100 \\
\hline
\end{tabular}

Water is a key resource which people ingest every day, if the concentration of iodine in the water is too high, it will affect the levels of iodine in the human body. After 2016, a WIC $>100 \mu \mathrm{g} / \mathrm{L}$ was defined as high level of iodine in water (GB/T 19380-2016). In this meta-analysis, it was found that when the WI was greater than $100 \mathrm{mg} / \mathrm{L}$, the OR of goiter development was 4.47 (95\% CI $1.15,19.46, P<0.001)$. Though the results of the Jia Q Z, and Tang Z C's study cross the invalid line and lack statistical significance, the OR values of the remaining studies within the meta-analysis were greater than 1 ; this suggests that high iodine levels lead to an increased risk of goiter development.

A Goiter is the enlargement of the thyroid. There was research found that excessive iodine intake will increase the synthesis of thyroid hormones and change the antigenicity of thyroglobulin, leading to the accumulation of colloid in the thyroid follicular cavity and flattening of thyroid follicular epithelial cells [28]. This is a typical pathological manifestation of goiter caused by high iodine. The decrease in thyroid hormone production caused by high iodine levels is called the Wolff-Chaik off effect [29]. Normally, thyroid hormone levels return to normal after a few days; this is termed the so-called "escape" phenomenon [30]. Although the mechanism by which high iodine causes goiter development remains unclear, failure to "escape" is considered to play a role. In addition, the continuous stimulation of thyroid stimulating antibodies activate NIS and/or spread lymphocyte infiltration; this may also play a role in high iodine levels causing the development of a goiter [31].

Clarifying the risk of high iodine on goiter development has important clinical and public health significance. Iodine is the main raw material in the synthesis of thyroxin. Changes in environmental iodine levels directly affect iodine intake; this in turn affects the subsequent changes in the synthesis and secretion of thyroid hormones. A study explored the effect of high parental 


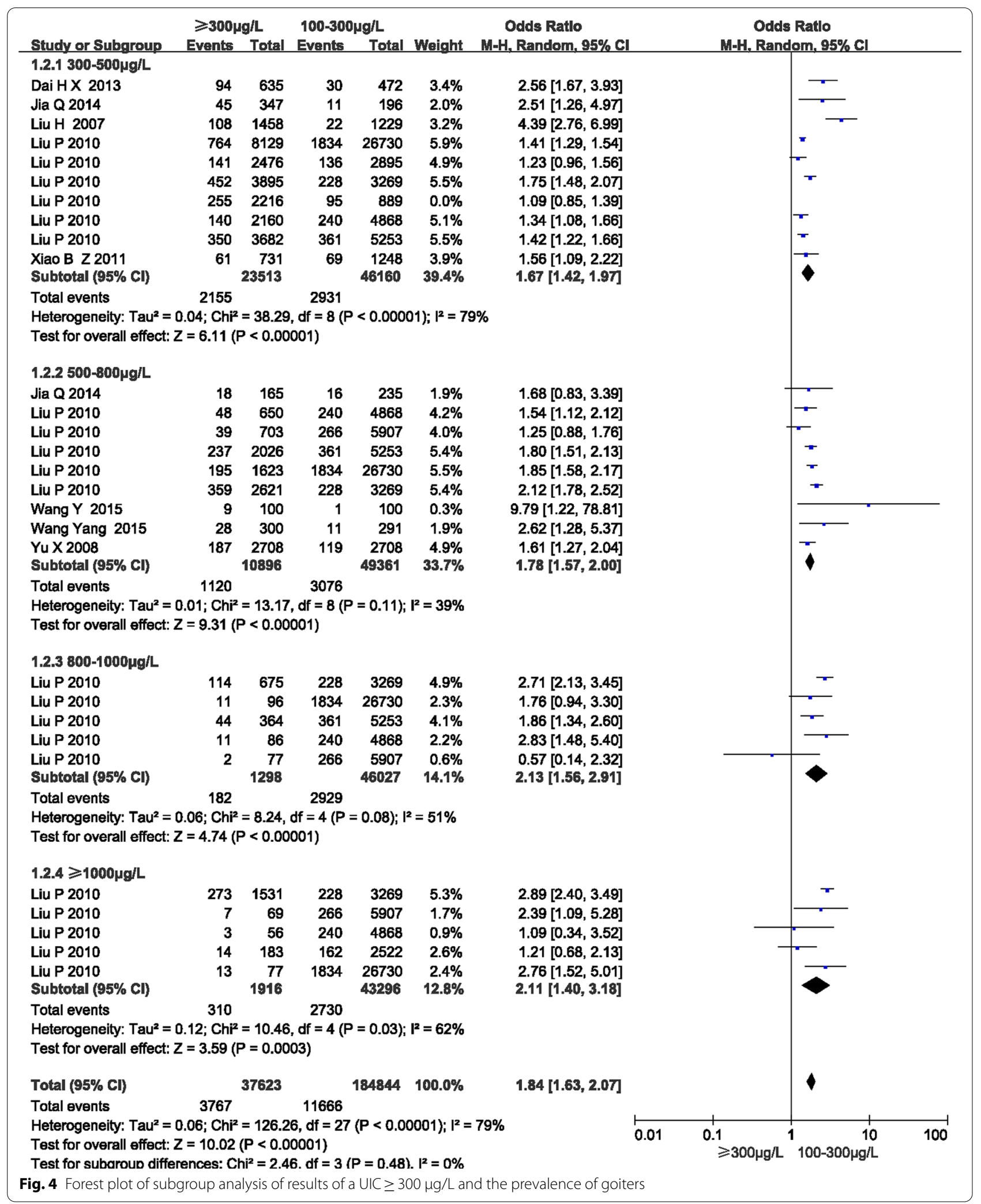


Table 2 mantel Haenszel $X^{2}$ test of UIC and goiter

\begin{tabular}{lllll}
\hline UIC $(\boldsymbol{\mu g} / \mathbf{l})$ & Goiter & Not goiter & $\mathbf{X}^{2}$ & $\boldsymbol{P}$ \\
\hline $100-300$ & 3405 & 53,918 & 734.605 & $<0.001$ \\
$300-500$ & 2499 & 24,157 & & \\
$500-800$ & 1381 & 11,732 & & \\
$800--1000$ & 182 & 1116 & & \\
$\geq 1000$ & 310 & 1606 & & \\
\hline
\end{tabular}

iodine levels on the thyroid hormone levels of offspring. First, parental mice were dosed with iodine using tap water containing iodine $(3000 \mu \mathrm{g} / \mathrm{L})$ for 4 months. At the end of the fourth month, the mice were paired for mating. The levels of thyroid hormone and TSH in the serum and brain of the offspring mice were then measured after birth. It was found that on the 14th day post-birth, the serum T4 level in the high iodine group was significantly reduced, whilst the serum TSH was higher than that of the control group [32]. Most healthy individuals can tolerate a high iodine intake. However, in certain susceptible populations, an excessive iodine intake may lead to hyperthyroidism [33], hypothyroidism [34], thyroid enlargement [35] and thyroid autoimmunity [36].

Considering the difficulty of conducting randomized trials and the absence of a meta-analysis of the relationship between high iodine intake and the development of a goiter, this study is of great significance for public health managers. These results confirm the necessity of monitoring iodine concentration in water and urine. The development of a goiter is a sensitive marker that reflects the long-term impact of a high iodine intake effect; the prevalence of goiters within a population has traditionally been a marker that reflects the long-term iodine status of a population.

This meta-analysis had several advantages. Firstly, this was the first meta-analysis assessing both UIC and WIC as iodine exposure markers; it was also the first which explored the risk of different high iodine levels on goiter development. secondly, it further confirmed that HUI and HWI can cause goiters, whilst also showing that urinary iodine and water iodine levels can be used as indicators of iodine exposure. Thirdly, in order to ensure the research quality of this meta-analysis, strict inclusion criteria were developed which helped to increase the robustness of the data. Finally, an extensive article retrieval and data extraction was conducted by 3 independent reviewers. At the same time, there are several limitations to the review. The included studies were cross-sectional studies, so the study is unable to determine causality between high iodine intake and goiter development. Also, as there is only limited relevant literatures for newborns, pregnant women, the elderly and other groups, only included school-age children were investigated in this meta-analysis. Further researches needed to be done to explore the relationship between high iodine levels and goiter development in newborns, pregnant women and the elderly.

\section{Conclusions}

In conclusion, the results of this meta-analysis showed that HUI or HWI increase the risk of the development of goiters. It also showed that as concentration of urinary iodine or water increased; the risk of goiter increaed.

\section{Abbreviations}

USI: Universal salt iodization; HUl: High urinary iodine; HWl: High water iodine; CNKI: China National Knowledge Infrastructure; UIC: Urinary lodine concentration; WIC: Water iodine concentration; OR: Odds ratio; Cl: Confidence interval.

\section{Acknowledgements}

Thanks to the National Natural Science Foundation of China for its financial support; thanks to the Tianjin Medical University Library for providing a free document retrieval platform; thanks to Tianjin Medical University School of Public Health and Tianjin Key Laboratory of Environmental Nutrition and Human Health for providing a good environment for paper retrieval and writing.

\section{Authors' contributions}

The authors' responsibilities were as follows—LT: designed the research; TX: performed the statistical analysis, conducted the meta-analysis and drafted the paper; TX, ZR and SL: provided essential materials; WZ and LT: provided comments and edits for the paper; TX, ZR and SL: had primary responsibility for the final content. All authors read and approved the final manuscript.

\section{Funding}

Dr. Long-Tan was supported by grants from National Natural Science Foundation of China $(81703218,82073549)$. Supported by the Tianjin Key Laboratory of Environment, Nutrition and Public Health and the Center for International Collaborative Research on Environment, Nutrition and Public Health.

\section{Availability of data and materials}

The datasets used and/or analysed during the current study are available from the corresponding author on reasonable request.

\section{Declarations}

Ethics approval and consent to participate Not applicable.

\section{Consent for publication}

Not applicable.

\section{Competing interests}

The authors declare that they have no competing interests.

Received: 12 October 2020 Accepted: 12 March 2021

Published online: 03 May 2021

\section{References}

1. Carvalho AC, Machado A, Embalo AR, Bordalo AA. Endemic goiter and iodine deficiency status among Guinea-Bissau school-age children. Eur J Clin Nutr. 2018;72(11):1576-82. 
2. Cao XY, Jiang XM, Dou ZH, Rakeman MA, Zhang ML, O'Donnell K, et al. Timing of vulnerability of the brain to iodine deficiency in endemic cretinism. $N$ Engl J Med. 1994;331(26):1739-44.

3. Dold S, Zimmermann MB, Jukic T, Kusic Z, Jia Q, Sang Z, et al. Universal salt iodization provides sufficient dietary iodine to achieve adequate iodine nutrition during the first 1000 days: a cross-sectional multicenter study. J Nutr. 2018;148(4):587-98.

4. Leung AM, Braverman LE. Consequences of excess iodine. Nat Rev Endocrinol. 2014:10(3):136-42

5. Wan SY, Jin BM, Ren BX, Qu MY, Wu HY, Liu LX, et al. The relationship between high iodine consumption and levels of autoimmune thyroiditisrelated biomarkers in a Chinese population: a meta-analysis. Biol Trace Elem Res. 2019.

6. Chen W, Li X, Wu YL, Bian JC, Shen J, Jiang W, et al. Associations between iodine intake, thyroid volume, and goiter rate in school-aged Chinese children from areas with high iodine drinking water concentrations. Am J Clin Nutr. 2017;105(1):228-33.

7. Wang Y, Cui Y, Chen C, Duan Y, Wu Y, Li W, et al. Stopping the supply of iodized salt alone is not enough to make iodine nutrition suitable for children in higher water iodine areas: A cross-sectional study in northern China. Ecotoxicol Environ Saf. 2020;188.

8. Lv S, Xie L, Xu D, Wang Y, Jia L, Du Y. Effect of reducing iodine excess on children's goiter prevalence in areas with high iodine in drinking water. Endocrine. 2016;52(2):296-304

9. WHO/UNICEF/ICCIDD. Assessment of iodine deficiency disorders and monitoring their elimination: a guide for program managers, 3rd ed. Geneva: WHO; 2007. p. 33

10. SAC. Definition and demarcation of water-borne iodine-excess areas and iodine-excess endemial areas in Chinese: GB/T 19380—2016. Beijing: China Standards Press; 2016.

11. Rostom A, Dubé C, Cranney A. Celiac disease. Evid Rep Technol Assess Summ. 2004;104(104):1-6.

12. Higgins JPT, Thompson SG, Deeks JJ, Altman DG. Measuring inconsistency in meta-analyses. BMJ. 2003;327(7414):557-60.

13. Higgins JPT, Green S. Cochrane handbook for systematic reviews of interventions version 5.1.0. The Cochrane Collaboration; 2011.

14. Egger M, Davey Smith G, Schneider M, Minder C. Bias in meta-analysis detected by a simple, graphical test. BMJ. 1997;315(7109):629-34.

15. Liu P, Liu SJ, Su XH, Zhang SB, Ji XH. Relationship between urinary iodine and goiter prevalence: results of the Chinese national iodine deficiency disorders survey. J Endocrinol Invest. 2010;33(1):26-31.

16. Wang Y, Jia Q, Zhang X, Guo B, Zhang F, Ren Y. Analysis of monitoring data in high water iodine areas in Shanxi Province in 2012. Chin J Endemiol. 2015;34(3):195-8.

17. Xiao BZ, Liu SJ, Wang HJ, Chen J, Cha G, Ma BC, et al. Comparative analysis of the survey results of iodine deficiency disorders between high-risk areas in Chongqing and in Linzhi of Tibet in 2007. Chin J Endemiol. 2011;30(1):76-80.

18. Jia Q, Zhang X, Ren Y, Guo B, Wang Y. Effects of different iodine concentration in drinking water on iodine nutrition, thyroid function and volume. Chin J Endemiol. 2014;33(5):540-4.

19. Wang Y, Hou C, Cui Y, Zhao L, Feng B, Fu G, et al. An investigation of iodine nutritional status and thyroid function among school-age children in high water iodine areas of Tianjin in 2014. Chin J Endemiol. 2015;34(7):518-21.
20. Yu X, Fan C, Shan Z, Teng X, Guan H, Li Y, et al. A five-year follow-up study of goiter and thyroid nodules in three regions with different iodine intakes in China. J Endocrinol Invest. 2008;31(3):243-50.

21. Liu H, Zeng Q, Han S, Zhan W. Effect of high iodine concentration in drinking water on thyroid function of elementary school student in Tianjin. Wei sheng yan jiu $=J$ Hyg Res. 2007;36(3):350-2

22. Tang ZC, Jiang XK, Liang W, Zhang L, Yang JY. Investigation on the distribution of high iodine region and inhabitant iodine nutritional status in the city of Liaocheng. Chin J Endemiol. 2006;25(6):683-5.

23. Jia QZ, Zhang XD, Wang ZH, Li J, Wen XP, Guo BS, et al. An epidemiological study on the distributive characters and the harm of high water iodine in Shanxi Province. Chin J Endemiol. 2006;25(3):294-6.

24. Dai $\mathrm{HX}$, Zeng P, Wang KY, Zhang XG, Ma ZJ, Zhou YG, et al. Analysis of a survey results of patients with suspected high iodine goiter in Liuji Town Fuping County of Shaanxi Province. Chin J Endemiol. 2013;32(4):408-11.

25. Disorders WUICftCoID. Assessment of iodine deficiency disorders and monitoring their elimination: a guide for programme managers: Geneva: WHO; 2007.

26. Pearce EN, Caldwell KL. Urinary iodine, thyroid function, and thyroglobulin as biomarkers of iodine status. Am J Clin Nutr. 2016:104(3):898s-901s.

27. Serra-Majem L, Pfrimer K, Doreste-Alonso J, Ribas-Barba L, Sanchez-Villegas A, Ortiz-Andrellucchi A, et al. Dietary assessment methods for intakes of iron, calcium, selenium, zinc and iodine. Br J Nutr. 2009;102(Suppl 1):S38-55.

28. Saboori AM, Rose NR, Bresler HS, Vladut-Talor M, Burek CL. Iodination of human thyroglobulin $(\mathrm{Tg})$ alters its immunoreactivity. I. lodination alters multiple epitopes of human Tg. Clin Exp Immunol. 1998;1 13(2):297-302.

29. Wolff J, Chaikoff IL. Plasma inorganic iodide as a homeostatic regulator of thyroid function. J Biol Chem. 1948;174:555-64.

30. Eng PH, Cardona GR, Fang SL, Previti M, Alex S, Carrasco N, et al. Escape from the acute WolffChaikoff effect is associated with a decrease in thyroid sodium/iodide symporter messenger ribonucleic acid and protein. Endocrinology. 1999;140:3404-10.

31. Farebrother J, Zimmermann MB, Andersson M. Excess iodine intake: sources, assessment, and effects on thyroid function. Ann NY Acad Sci. 2019;1446(1):44-65.

32. Guo HL, Hou XH, Yang XF, Xu J. Influences of excess iodine on thyroid hormone concentrations in cerebrum of filial mice and intervention of selenium. Wei Sheng Yan Jiu. 2006;35(2):194-5.

33. Roti E, Uberti ED. lodine excess and hyperthyroidism. Thyroid. 2001:11(5):493-500.

34. Kang MJ, Hwang IT, Chung HR. Excessive iodine intake and subclinical hypothyroidism in children and adolescents aged 6-19 years: results of the sixth Korean National Health and Nutrition Examination survey, 2013-2015. Thyroid. 2018;28(6)::773-9.

35. Prakash R. High thyroid volume in children with excess dietary iodine intakes. Am J Clin Nutr. 2005:82(3):708-9.

36. Rayman MP. Multiple nutritional factors and thyroid disease, with particular reference to autoimmune thyroid disease. Proc Nutr Soc. 2019;78(1):34-44.

\section{Publisher's Note}

Springer Nature remains neutral with regard to jurisdictional claims in published maps and institutional affiliations.

Ready to submit your research? Choose BMC and benefit from:

- fast, convenient online submission

- thorough peer review by experienced researchers in your field

- rapid publication on acceptance

- support for research data, including large and complex data types

- gold Open Access which fosters wider collaboration and increased citations

- maximum visibility for your research: over 100M website views per year

At BMC, research is always in progress.

Learn more biomedcentral.com/submissions 